\title{
The Place of Study of Nature in Jabir Ibn Hayyan's Classification of Science
}

\author{
Marziyehsadat Montazeritabar ${ }^{1,2}$, Zaiqing Fang ${ }^{1}$ \\ ${ }^{1}$ Institute for the History of Natural Sciences, Chinese Academy of Sciences, Beijing, China \\ ${ }^{2}$ University of Chinese Academy of Sciences, Beijing, China \\ Email: msmt@ihns.ac.cn, fang@ihns.ac.cn
}

How to cite this paper: Montazeritabar, M., \& Fang, Z. Q. (2020). The Place of Study of Nature in Jabir Ibn Hayyan's Classification of Science. Advances in Historical Studies, 9, 85-91.

https://doi.org/10.4236/ahs.2020.93007

Received: August 18, 2020

Accepted: August 23, 2020

Published: August 26, 2020

Copyright (c) 2020 by author(s) and Scientific Research Publishing Inc. This work is licensed under the Creative Commons Attribution International License (CC BY 4.0).

http://creativecommons.org/licenses/by/4.0/ (c) (i) Open Access

\begin{abstract}
One of the Muslim pioneers of the golden age of Islamic civilization is Jabir ibn Hayyan, polymath and alchemist of the eighth century CE. In this study, we briefly explain Jabir's biography and the significance of his scientific character in the history of science. Then, we investigate Jabir's attitude about the classification of science and the position of the study of nature in his thought. Jabir divides science into two main categories: the science of earth and the science of religion. He considers natural science as a type of rational science which is a subcategory of the science of religion. We discuss that the conceptual framework of Jabir in the classification of science has some similarities with other Muslim scholars.
\end{abstract}

\section{Keywords}

Jabir Ibn Hayyan, Classification of Science, Study of Nature, Islamic Civilization

\section{Introduction}

When Islamic civilization dawned by the emerge of Islam in the seventh century $\mathrm{CE}$, the seed of knowledge was fertilized in the Islamic realm and it was after about a century (i.e., the eighth century CE) that it yielded. This is the beginning of a period of flourishing of Islamic sciences, known as the Islamic golden age. This era is full of scholars who have sought knowledge, and performed original scientific works. The study of nature was one of the branches of knowledge at that time, which had considerable progress in association with other branches of knowledge.

Abu Musa Jabir ibn Hayyan (ca. 721-815 CE) is one of the pioneers in the field of study of nature in the golden age of Islam. He was a Muslim polymath 
and alchemist who has left many scientific works and achievements. Although there are different opinions about the exact time of living of Jabir, he was recognized as one of the most renowned ones in the field of alchemy (Haq, 1994). Indeed, Jabir smoothed the path for the alchemists after him, including al-Razi and al-Tughrai, who lived in the $9^{\text {th }}-13^{\text {th }}$ centuries CE. In the West, Jabir has also retained his reputation as the master of professors in the science of chemistry. Professor Berthelot, a well-known French chemist, is strongly influenced by Jabir and says: "Jabir had the same rank in chemistry as Aristotle had in the science of logic" (Berthelot, 1983).

Since the subject, purpose, and methods of research in natural sciences in Islamic civilization is influenced by Islamic epistemology (Montazeritabar, 2019), recognizing Jabir's classification of knowledge is of paramount importance as a methodological subject to understand the place of study of nature in his view. In this regard, we focus on Jabir's Kitab al-Hodud (The Book of Definitions) wherein he introduces his classification of knowledge. In the following, we first explain Jabir's biography and the significance of Jabir's achievements briefly.

\section{Jabir's Biography and the Importance of His Scientific Character}

There are different points of view regarding Jabir's entity. Shiite (a member of one of the two main groups of Muslim religion) counts Jabir among themselves and know him as a friend of Ja'far al-Sadiq (the sixth true Calipha or Imam and rightful successors of Islam Prophet, Muhammad ibn Abdullah). However, some others claim that Jabir was belonging to Barmakian and he was specifically a proponent of Jafar ibn Yahya. They also argue that Jabir had a Baramaki master with the name of Ja'far, but Shiite scholars claim that Jafar implies Imam al-Ja'far.

Ibn Al-Nadim ( $10^{\text {th }}$ century CE) has mentioned in his famous book (Al-Fihrist) that a chemist had told him that Jabir was living mostly in Kufa and doing Elixir there because of good weather condition. In the city of Kufa, a pounder was found in the years between 967-977 CE wherein there were 200 pounds of gold and near that there was an apparatus for the dissolution and stabilization of materials. This place was formerly known as Jabir's house (Ibn Al-Nadim, 1994). While Jabir mostly settled in Iraq and Syria, he has sometimes referred to his travels to India and Egypt. The year of Jabir's death is unknown. Some people say it occurred in $776 \mathrm{CE}$ and some others mentioned it happened in the years between 813-833 CE.

Jabir has a large contribution to the development of alchemy. Maslama al-Majriti writes: "But the scientist who was completely superior in this industry and above all else was most exalted Shaykh Abu Musa Jabir ibn Hayyan Sufi; Yes, he is the founder of the Science of Balance. In the natural sciences, he had a perfect prevalence, and he was skillful in the craft of alchemy, he has several famous compilations in this field, and besides, he was knowledgeable about other philosophical sciences ... Muhammad bin Sa'id al-Hasr, al-Din known as Ibn al-Mashat al-Astarlabi al-Andalusi, has mentioned that I saw a book in Medina of Egypt, 
attributed to Jabir ibn Hayyān in the practice of Astrolabe containing one thousand of problems that were unprecedented" (Al-Majriti, 2008).

In the Medieval Ages, the alchemical texts of Jabir were translated into Latin and became the main texts for the alchemists in the West. Jabir's books strongly impacted the Western alchemists of the medieval Ages and tuned their exploration for the philosopher's stone (Ragai, 1992). For example, Robert of Chester (1144) translated the Kitab al-Kimya (which was titled Book of the Composition of Alchemy in Europe), Gerard of Cremona (before 1187) translated the Kitab al-sab'in (The Book of seventy). More recently, Marcelin Berthelot translated some of Jabir's books under the fanciful titles Book of the Kingdom, Book of the Balances, and Book of Eastern Mercury.

Jabir invented some technical terms in the Arabic language, such as alkali. These terms penetrated into various European languages and have become part of technical parlance. Max Meyerhof states about Jabir ibn Hayyan: "His influence may be traced throughout the whole historic course of European alchemy and chemistry" (Dungersi, 1999).

Eric John Holmyard, a famous historian of science and technology, recognizes Jabir as a person who transformed alchemy into an experimental science and mentions that: "Jabir was trying to liberate the science of chemistry with the help of his master (Imam Ja'far al-Sadiq) from the ancient legends of the school of Alexandria, and in this way, he could achieve to a great extent and he became successful. Henceforth, the name of Jabir coincides with the names of the great scholars of this science, such as Boyle and Priestley, and Lavoisier" (Holmyard, 1931). George Sarton says: "Jabir should be regarded as the greatest scientist in the field of science during the Middle Ages" (Sarton, 1927).

Paul Kraus, a historian who extensively studied Arabic and Latin works of Jabir, outlined the significance of Jabir in the history of chemistry by making a comparison between his experimental-based works in chemistry and that of the incomprehensible works of the alchemists in the ancient Greek (Kraus, 1942).

\section{Classification of Knowledge and the Place of Study of Nature in It}

Since in the Jabir's cosmology, the world of nature is a component of the universe and it is in perfect harmony with the universe, the study of nature is also part of the knowledge of the whole of existence, and not apart from it. According to this view, a scientific proposition cannot be in conflict with the cosmological proposition. All types of knowledge are united and each of them looks to the universe from a specific perspective and any knowledge is not an antithesis to the other knowledge. At the same time, this unity between the sciences does not stop the specialization of science, and each of these sciences is divided into several branches. Figure 1 outlines the classification of science from Jabir's perspective. 


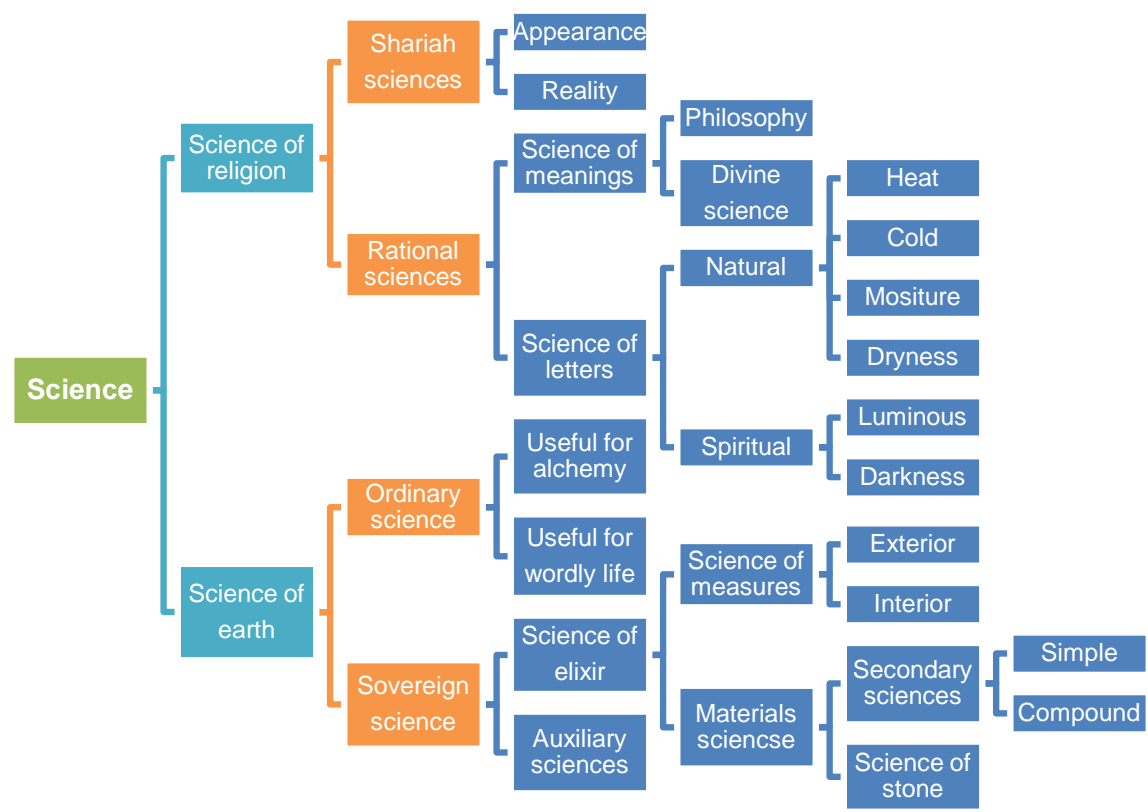

Figure 1. The flow chart illustrating Jabir's classification of science.

Jabir's classification of science is formed by dividing science into two categories: the science of religion and the science of the earth. The science of religion is the science that comes from the intellect and the use of this science makes it possible to achieve the benefits that hope to expect after death (Jabir ibn Hayyan, 2009) $)^{1}$. The intrinsic nature of the science of religion is that it has an afterlife advantage for mankind and not a worldly benefit. Although with the acquisition of these sciences one can gain a worldly benefit, this is the accidental aspect of the science of religion and not its intrinsic aspect.

Then, Jabir classifies the science of religion into two branches: Shariah sciences and rational sciences. Shariah science is a science that its purpose is to recognize the most beneficial methods in this world and the world hereafter; of course, those worldly profits that benefit humans after death (Jabir ibn Hayyan, 2009) ${ }^{2}$.

The rational science is the recognition of affairs that are not accessed by the sense perceptions, and the minor intellect is adorned by recognizing them. The examples of rational sciences include knowledge of the condition of the first cause, the state of minor intellect, the conditions of the universal intellect, and minor soul and universal soul. Understanding these sciences leads to the acquisition of virtue in this world and the attainment of the perpetuity in the world hereafter (Jabir ibn Hayyan, 2009)3. According to this definition, human's intellect can contact the realm of divinity.

The branches of rational science in Jabir's classification are the science of letters and the science of meanings. Jabir defines the science of meanings as the complete recognition of the principle, traits, and the existential purpose of objects. "On the one hand, there is philosophy: it is the knowledge of the truths of ${ }^{1}$ Jabir. Kitab al-Hudud, p. 103.

${ }^{2}$ Loc. cit.

${ }^{3}$ Ibid. p. 105. 
the beings which are a function of the causation system, and embraces the study of nature, astronomy, calculus, and geometry. On the other hand, there is divine science; Theology is the science of metaphysical truths, the first cause, the universal intellect, the universal soul" (Lory, 2003).

The science of earth is the science that is obtained by intellect and soul and its purpose is to attract the benefit and dispose of harm before death (Jabir ibn Hayyan, 2009) ${ }^{4}$. Science of earth is inherently for acquiring profit and disposing of harm in this world. Science of the earth is divided into Sovereign Science and Ordinary Science.

Sovereign Science is the knowledge that makes mankind independent of all people to create a good life. And that is the knowledge of elixir. Sovereign Science supplies mankind with the unordinary ways to reach self-sufficiency in making incomes.

Ordinary Science is the knowledge which provides the pleasures and interests of the human being before death and preserves his life. In other words, Ordinary Science is the knowledge of the things people need in order to attain their worldly interests. This type of science supplies medium or inferior profits of mankind through ordinary ways (Jabir ibn Hayyan, 2009) 5

\section{Analysis of Jabir's Classification}

It seems that Jabir has classified science in the first place on the basis of the purpose or the temporal priority of the profit of science: the sciences that are useful for the humans in another world, and the sciences that are useful to his life in this world (Akyol, 2018); In other words, the sciences which have a theoretical value and the sciences that have practical worthiness. The first category is those sciences in which the authentic issue is the discovery of truths in them, but in the second category of science, the practical and instrumental usage of these sciences has the authenticity.

The rational sciences in Jabir's thought and theoretical intellectual sciences in the view of Muslim scholars are sciences which informs us about the existence and nature of bodies of matter, so that our soul may find its own form, and will be blissful in the world hereafter (Ibn Sina, 1953). In other words, the goal of rational sciences is to prosper in the world hereafter.

From the perspective of Jabir, the science of meaning of letters is divided into two categories: the first one is the knowledge of creatures, that is philosophy; and the other one is the knowledge of the Creator, that is theology. Therefore, natural science, as it deals with the affairs of nature as a creature, is regarded as a variety of philosophy.

The division of science of religion into Shariah sciences and rational sciences is akin to the division of intellectual science or wisdom into practical and theoretical ones. Shariah science, similar to the practical wisdom, is related to the field of human performance, while and rational sciences, similar to theoretical 
wisdom, are related to the recognition of the states of creatures. Thus, it seems that Jabir has considered the criterion of the subjects (accessories) of cognition in the classification of the science of religion into Shariah sciences and rational sciences. Or, perhaps it can be said that the science of religion is of two types, some of them are directly based on the teachings, and some others are based on rational precepts (Naguib Mahmoud, 1962).

The division of the science of religion is based on the criterion of the method of acquiring knowledge. In this regard, Shariah sciences are transitive and rational sciences are intellectual. It should be noted that it may also not possible to take into account the criterion of method because in Shariah sciences, sometimes the appearance of the text is cited and sometimes esoteric interpretations are cited, and these esoteric interpretations are received by the instrument of intellect.

Another point is that in the classification of Jabir, we are facing a holistic view of science followed by the branches of various sciences. This unilateral approach is accompanied by some characteristics introduced to separate the branches and subcategories of science in the mind of Jabir. In fact, a kind of epistemic and scientific unity is combined with component and disciplinary specialization and Jabir has exhibited a demonstration of the unity of sciences while differentiating them from one another.

Jabir regards natural science as the science that is out of reach of the senses and is received only with intellect. This is because he regards natural science as the knowledge to the truth of the beings, and this knowledge to their truth derives from reason, not through senses. Although the senses are used to enter the natural sciences and the use of senses is an entrance for the natural sciences, the senses are not considered an independent tool and they have a secondary aspect.

It seems that in view of Muslim scholars, the senses and experiment are not independent methods in the natural sciences because they consider natural science as the knowledge of the truth of the matter, and this knowledge is possible to obtain only by the intellect. With the senses, only the appearance of the objects is understood, not their truth. Understanding the appearance of objects is not a natural science, but it is an introduction to natural science. So, the senses are not considered an independent method while the rational method is an independent and principal method. It is important to note that when Muslim scholars divide science according to the method, they call a group of sciences as rational sciences while recognizing no group as sensational science. That is, science is divided into sciences that are derived using intellect and those which are obtained without the use of intellect (such as Islamic traditional sciences).

In addition, wherever the sensory and experimental methods are used, we also have a rational method. Due to the existence of a secret argumentation in all experiences, the sensory and experimental methods are always along with the rational method. For this reason, in all classifications, natural science is a subcategory of rational sciences, not sensational sciences, although they benefit from the sense and experiment. 


\section{Conclusion}

The importance and the place of study of nature in the thought of Jabir were investigated in this study. Jabir believes in the unity of sciences while differentiating them from one another. He regards the study of nature as a subcategory of rational sciences which is a subdivision of the science of religion. The infrastructure of Jabir's classification of science has some common characteristics with other classifications of sciences among Muslim scholars during the golden age of Islamic civilization.

\section{Acknowledgements}

M. M. acknowledges financial support from the CAS-TWAS President's Fellowship Programme.

\section{Conflicts of Interest}

The authors declare no conflicts of interest regarding the publication of this paper.

\section{References}

Akyol, A. (2018). Jabir Ibn Hayyan's Classification of Science And Its Place in Islamic Epistemology. Turkish Journal of Religious Studies, 18, 11-22.

Al-Majriti (2008). Qayat al-Hakim fi Ersad al-Malakiyah va al-talasem al-ruhiya va al-Tanjim. Beirut: Dar Al Mahaja.

Berthelot, M. (1983). La Chimie au Moyen Äge III. Paris: Imprimerie nationale.

Dungersi, M. R. (1999). A Brief Biography of Imam Jafar bin Muhammad (a.s.). Dar es Salaam: Bilal Muslim Mission of Tanzania.

Haq, S. N. (1994). Names, Natures and Things: The Alchemist Jäbir ibn Hayyān and his Kitāb al-Ahjār. Dordrecht and Boston: Kluwer Academic.

https://doi.org/10.1007/978-94-011-1898-9

Holmyard, J. E. (1931). Makers of Chemistry. Oxford: Clarendon Press.

Ibn Al-Nadim (1994). Al-Fihrist (I. Ramazan, Ed.). Beyrut: Daru'l-Mearif.

Ibn Sina (1953). Encyclopedia of Alayi (M. Moein, Ed.). Hamedan: Bu Ali Sina University Press.

Jabir ibn Hayyan (2009). Kitab al-Hudud(P. Kraus, Ed.). Cairo: Maktabat al-Khānji.

Kraus, P. (1942). Jabir ibn Hayyan: Contribution à l'histoire des idees scientifiques dans I'Islam. Vol. II: Jabir et la science grecque. Cairo: Maktabat al-Khānji.

Lory, P. (2003). Alchimie et mystique en terre d'Islam. Paris: Verdier.

Montazeritabar, M. (2019). Epistemological Foundations of Natural Sciences in Islam. Open Journal of Philosophy, 9, 63-71. https://doi.org/10.4236/ojpp.2019.92006

Naguib Mahmoud, Z. (1962). Jabir Ibn Hayyan. Cairo: Maktabat 'al-Misr.

Ragai, J. (1992). The Philosopher's Stone: Alchemy and Chemistry. Journal of Comparative Poetics, 12, 58-77. https://doi.org/10.2307/521636

Sarton, G. (1927). Introduction to the History of Science: From Homer to Omar Khayyam. (Vol. 1). Baltimore, MD: Williams \& Wilkins Company. 